\title{
Potential of Holocene deltaic sequences for subsidence due to peat compaction
}

\author{
E. Stouthamer and S. van Asselen \\ Dept. of Physical Geography, Faculty of Geosciences, Utrecht University, Utrecht, the Netherlands \\ Correspondence to: E. Stouthamer (e.stouthamer@uu.nl)
}

Published: 12 November 2015

\begin{abstract}
Land subsidence is a major threat for the livability of deltas worldwide. Mitigation of the negative impacts of subsidence, like increasing flooding risk, requires an assessment of the potential of the deltas' subsurfaces for subsidence. This enables the prediction of current and future subsidence and optimization of sustainable management strategies. In this paper we present a method to determine the amount of compaction within different Holocene deltaic peat sequences based on a case study from the Rhine-Meuse delta, the Netherlands, showing the potential of these sequences for subsidence due to peat compaction.
\end{abstract}

\section{Introduction}

Land subsidence is a major threat to hundreds of millions of people living in deltas worldwide. It leads to increasing flooding risk, damage to buildings and infrastructure, intrusion of salt water, and hence, has a negative impact on the livability in deltas. Natural subsidence rates, caused by tectonics, isostasy, sediment compaction and oxidation of organic material are generally in the order of $\mathrm{mm} \mathrm{yr}^{-1}$ (van Asselen et al., 2011). Human-induced subsidence rates, due to extraction of groundwater, oil and gas, drainage for land reclamation, and loading by for example roads and buildings are commonly an order of magnitude higher $\left(\mathrm{cm} \mathrm{yr}^{-1}\right.$; e.g. van Asselen, 2011; Erban et al., 2014). Consequently, in many populated deltas the contribution of subsidence to relative sea-level rise is much larger than eustatic (absolute) global sea-level rise, which is in the order of $\mathrm{mm} \mathrm{yr}^{-1}$ (Church et al., 2013).

The potential of delta sequences for both natural and human-induced subsidence due to compaction and oxidation of peat, and hence subsidence magnitude and rate, is highly variable in time and space, mainly depending on the composition of the subsurface. Subsurface composition and characteristics are determined by the palaeogeographical development (i.e. the spatial and temporal distribution of depositional environments and hence deposits), post-depositional processes of erosion (i.e. preservation) and loading, and physical, geochemical and biological processes, including compaction and soil formation. Based on the 3-D distribution of specific sequences within a delta and their physical properties, the potential for subsidence due to peat compaction of these sequences at the spatial scale of an entire delta can be determined.

To mitigate the negative impacts of human-induced subsidence it is essential to know the potential of the subsurface for compaction and oxidation. This enables the prediction of current and future subsidence under different delta management strategies and to develop and optimize sustainable management strategies. In this paper we present a method to determine the amount of peat compaction for typical Holocene distal deltaic organo-clastic sequences based on a case study from the Rhine-Meuse delta, the Netherlands, showing the potential of these sequences for subsidence due to peat compaction.

\section{Subsidence potential due to peat compaction}

Holocene delta sequences are usually very heterogeneous, and composed of alternating layers consisting of mixtures of sand, silt, clay and peat. The main factors influencing the potential for subsidence due to peat compaction are (1) the thickness of organic, mainly peat and clay, layers in the subsurface, (2) the organic matter content of these layers, and (3) the effective stress, which is a function of the weight of the overburden and pore water pressures (van Asselen et al., 


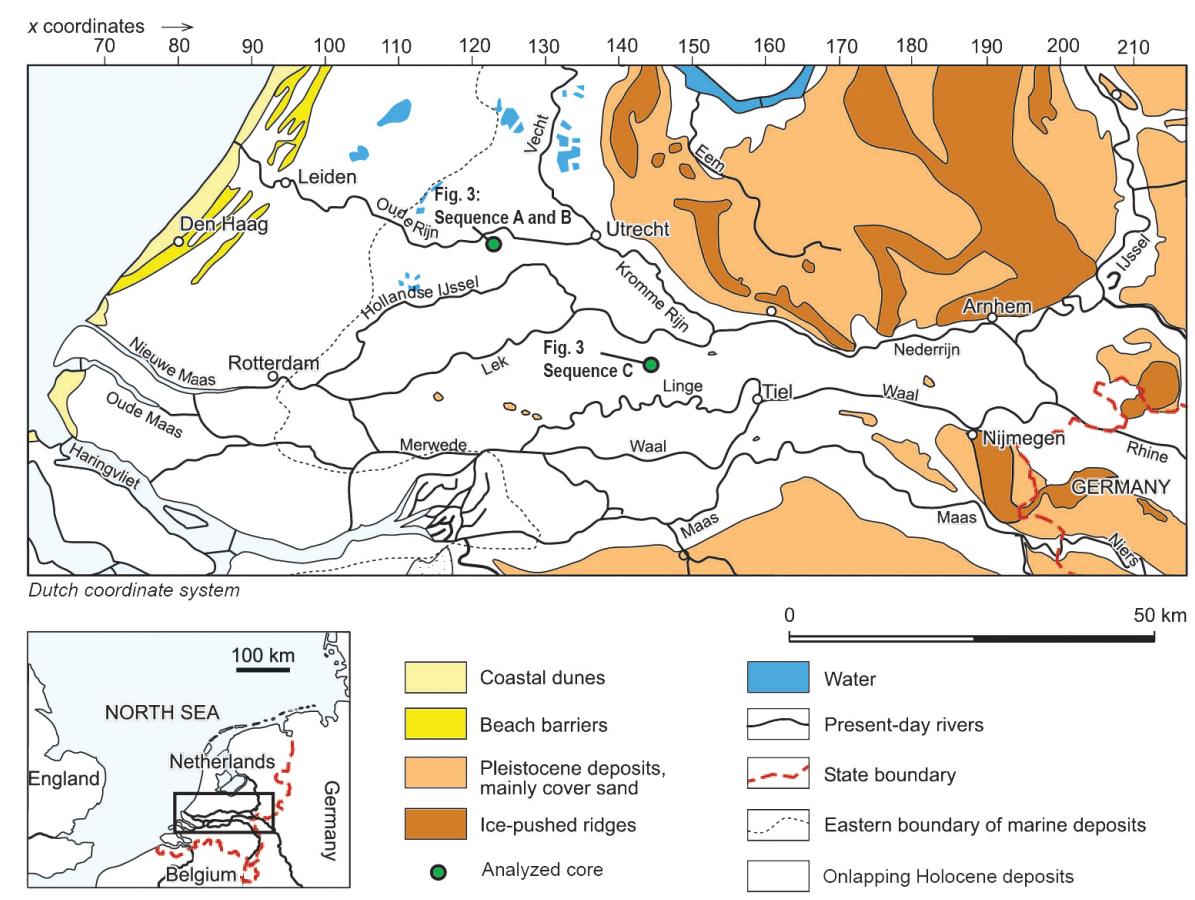

Figure 1. The Holocene Rhine-Meuse delta, the Netherlands; rivers run E-W. $x$ coordinates according to the Dutch map coordinate system (in kilometers, after Stouthamer and Berendsen, 2001 and Stouthamer et al., 2011).

2010). In addition, the Holocene sedimentation and groundwater table history is extremely important, because this determines if organic layers have experienced past compaction and/or oxidation, and hence their present geotechnical properties. Lowering of the phreatic groundwater level, for e.g. agricultural purposes, leads to a drop in hydrostatic pressure, causing diminishing pore water pressures and consequently an increase in effective stress ( $=$ total weight - pore water pressure; Terzaghi, 1943) and compaction of the peat sequence. At the depth interval between the former, higher, and new, lower, groundwater level, oxidation of organic material occurs. This leads to a decrease in volume and collapse of the original soil structure that existed before groundwater level was lowered. Both compaction and oxidation contribute to total subsidence. Sequences that are composed of thick high-organic peat layers, especially in the upper meters of the sequence have the highest potential for compaction and oxidation and hence subsidence. Compaction rates will be much lower if a peat layer has already experienced compaction by loading. Rates of compaction due to loading are highest within decades to a few centuries after loading (van Asselen et al., 2011).

\section{Study area: Rhine-Meuse delta, the Netherlands}

The Rhine-Meuse delta is located in the Netherlands, in the tectonically subsiding Southern North Sea Basin. The estimated Holocene-averaged basin subsidence rate is $0.1-$
$0.3 \mathrm{~mm} \mathrm{yr}^{-1}$ (Cohen, 2005). The Holocene delta was jointly formed by the rivers Rhine and Meuse. The delta apex is located near the Dutch-German border (East). The Rhine and Meuse debouch into the North Sea (West) (Fig. 1). The distance between the modern delta apex and the Rhine-Meuse river mouth is ca. $150 \mathrm{~km}$. The Holocene sequence is approximately $2 \mathrm{~m}$ thick near the delta apex and just over $20 \mathrm{~m}$ at the present river mouth and coastal barrier. The upstream part of the delta is confined by higher topography of sandy Pleistocene deposits (ice-pushed pre-Saalian glacial sandy Rhine and Meuse deposits) and relatively narrow; $15-25 \mathrm{~km}$ wide. Downstream the delta widens to $60 \mathrm{~km}$ and grades laterally into tidal-estuary and lagoonal coastal plain environments. The southern and central-northern part of the delta are bordered by higher topography formed by Late Glacial cover sand deposits. Between 1100 and $1300 \mathrm{AD}$ all Rhine and Meuse distributaries in the delta were embanked, stopping flood basins from receiving sediments (van de Ven, 2003). Flooding and channel-migration activity has since remained restricted to the embanked flood plains.

The Holocene subsurface of the delta, fed with sediment by the mixed-load rivers Rhine and Meuse, is notoriously heterogeneous. Channel-belt sand bodies dissect areas of overbank deposits (dominantly clayey, but holding sand and silt too). Multiple generations of channel belts avulsed adding further complexity (Stouthamer and Berendsen, 2000). Downstream in the delta, the overbank clastics alternate with peat layers (Fig. 2). The distal Holocene coastal, 


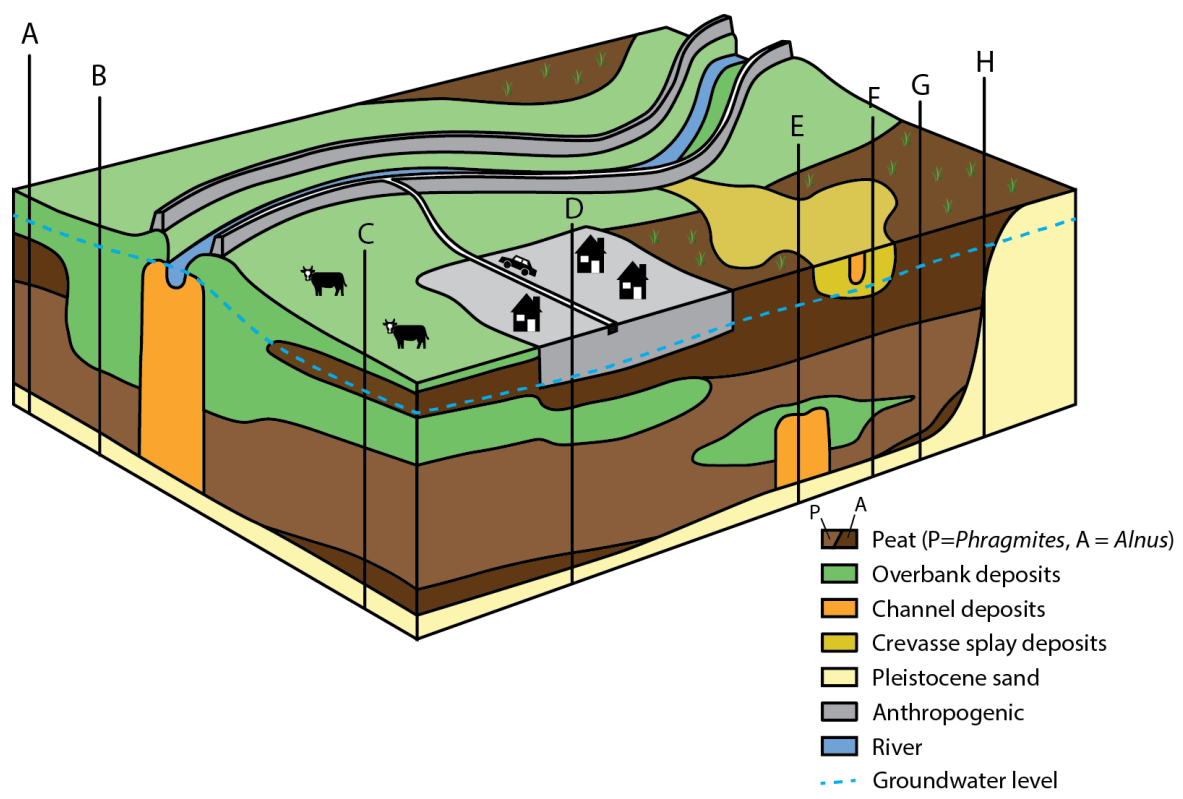

Figure 2. Schematic representation of the lithological subsurface composition of the distal (western) part of the Holocene Rhine-Meuse delta. The vertical lines $(\mathrm{A}-\mathrm{H})$ indicate different sequences with a varying potential for subsidence due to compaction and oxidation depending on the subsurface composition and characteristics.

tidal, estuarine and fluvial deposits are onlapping the Pleistocene cover sand deposits in the North and the South and braided river deposits in the central part of the delta (Fig. 1).

\section{Methods: determining the potential for compaction}

The Holocene sequence composition of the Rhine-Meuse delta is well-known from previous studies (e.g. Berendsen and Stouthamer, 2000; Stouthamer, 2001; Cohen, 2003; Gouw and Erkens, 2007; Gouw, 2008; Bos, 2010; Stouthamer et al., 2011). These studies allow to distinguish key clastic-organic sequences (Fig. 2), which have different potentials for subsidence due to peat compaction.

The degree of peat compaction has been determined at different locations in the organo-clastic central part of the Rhine-Meuse delta (van Asselen, 2011; Van Asselen, unpublished work; here we present three sequences $\mathrm{A}-\mathrm{C}$ in Figs. 1 and 3), by comparing the dry bulk density of compacted and uncompacted peat of similar organic-matter content (Bird et al., 2004; van Asselen et al., 2009; van Asselen, 2011). The dry bulk density and organic-matter content of compacted peat in a delta sequence are measured from sediment cores at 5 -cm intervals using a $1 \mathrm{~cm} \times 1 \mathrm{~cm} \times 5 \mathrm{~cm}$ sampler. The cores are extracted with a $100 \mathrm{~cm} \times 6 \mathrm{~cm}$ wide gouge auger, and subsequently cut in half lengthways using a thin stretched wire, to sample of the inner least disturbed part. The dry bulk density of each $5 \mathrm{~cm}^{3}$ peat sample has been determined by drying it at $105^{\circ} \mathrm{C}$ and weighing it on an electronic scale with an accuracy of $0.001 \mathrm{~g}$ (dry bulk density $=$ weight $/ 5 \mathrm{~cm}^{3}$ ). The organic-matter content has been determined by loss-on-ignition $(\mathrm{LOI}=((\mathrm{dried}$ weight - ashed weight) / dried weight) $\times 100 \%$; cf. Heiri et al., 2001). The dried peat samples were heated at $550{ }^{\circ} \mathrm{C}$ for $4 \mathrm{~h}$ and subsequently weighted to determine the ashed weight.

Uncompacted peat samples were obtained from the Biebrza National Park (Poland) and the Rhine-Meuse delta (van Asselen, 2011). The Biebrza National Park is a wetland that has experienced minimal human disturbance, where similar peat types occur as in the Holocene Rhine-Meuse delta. The fresh, uncompacted peat has been sampled using a special device that was designed for this purpose (van Asselen and Roosendaal, 2009). The dry bulk density and LOI of uncompacted peat samples were determined following the same procedure as for compacted $5 \mathrm{~cm}^{3}$ samples. Based on these data an equation for calculating the dry bulk density of uncompacted peat of any LOI has been constructed:

$\rho_{\mathrm{dry}, \text { uncompacted }}=a-c e^{-(b / \mathrm{LOI})}$,

in which $a, b$ and $c$ are fitted parameters (van Asselen, 2011). The calculated dry bulk density was subsequently used to calculate the decompacted thickness of each $5 \mathrm{~cm}^{3}$ compacted peat sample:

$h_{\text {decomp }}=\frac{\rho_{\text {dry, comp }}}{\rho_{\text {dry, uncomp }}} \times 5$.

The percentage of compaction is expressed as the ratio between the volume reduction 

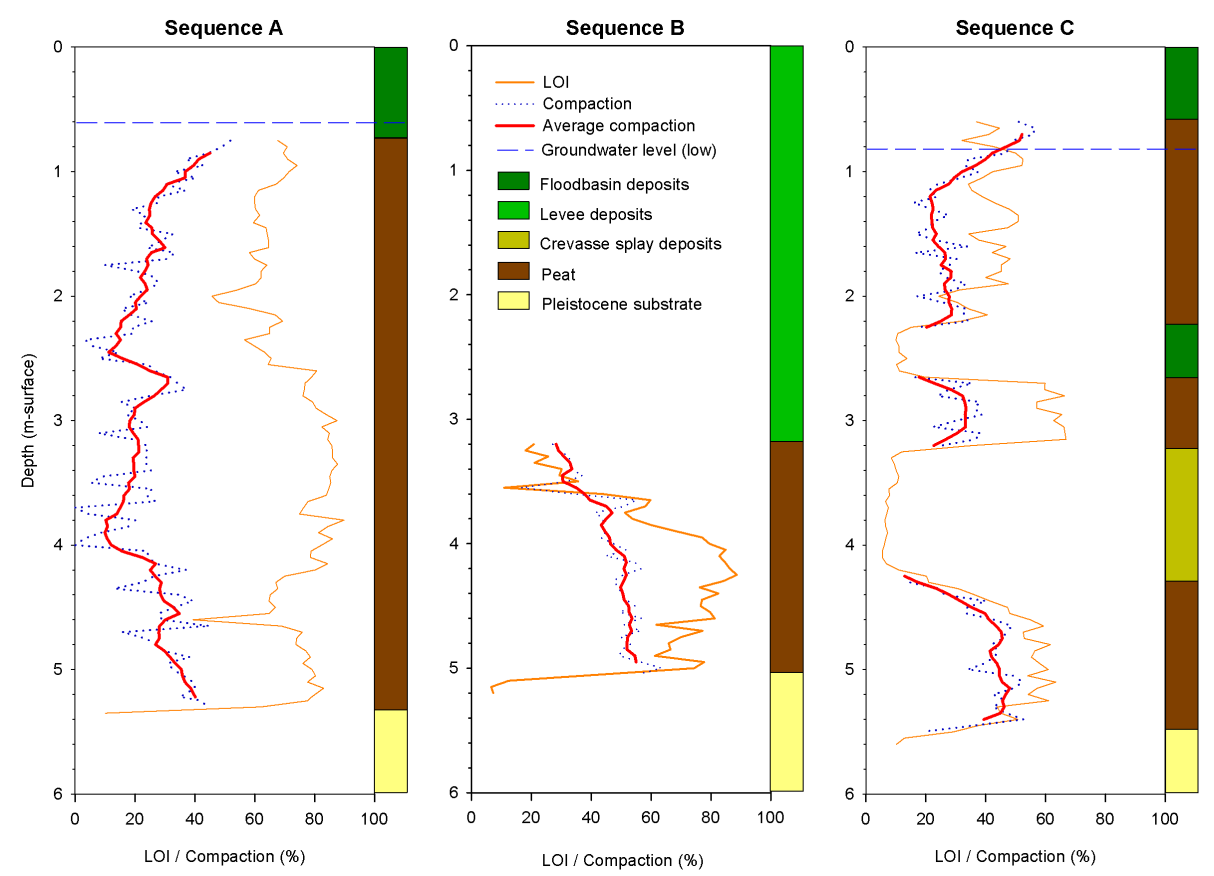

Figure 3. Lithological composition, LOI and amount of compaction of cores OR-I (sequence B), OR-II (sequence A), and CB-I (sequence C) (after van Asselen, 2011). These sequences are representative for the sequences A, B and C in Fig. 2.

$\left(v_{\text {red }}=\left(1 \times 1 \times h_{\text {decomp }}\right)-(1 \times 1 \times 5)\right)$ and the calculated decompacted volume of a $5 \mathrm{~cm}^{3}$ peat sample $\left(v_{\text {decomp }}=1 \times 1 \times h_{\text {decomp }}\right)$ :

compaction $=\frac{v_{\text {red }}}{v_{\text {decomp }}} \times 100 \%$.

\section{Results: compaction of sequences A-C}

Sequence B is located close to the river (Fig. 2) and is characterized by approximately $3 \mathrm{~m}$ of natural levee deposits on top of a 2-m-thick peat layer between 3-5 m below the surface that is situated on the incompressible Late-Pleistocene sand substrate (Fig. 3). Sequence A and C are located at further distance from the river (Fig. 2). Sequence A is characterized by a $60 \mathrm{~cm}$ thick layer of flood basin deposits on a $4.5 \mathrm{~m}$ thick peat layer on the Late-Pleistocene sand substrate (Fig. 3). Sequence C comprises alternating layers of peat and fluvial deposits; $50 \mathrm{~cm}$ of flood basin deposits at the top, $30 \mathrm{~cm}$ flood basin deposits at 2.20-2.40 m depth and $1 \mathrm{~m}$ of crevasse-splay deposits at 3.20-4.20 m depth.

Fluctuating LOI-values within the sequences can be explained by the varying clastic content; deposits with a high clastic content show low LOI-values (e.g. flood basin deposits, clayey peat intervals), deposits with a low clastic content show high LOI-values (e.g. peat). For sequences B and $\mathrm{C}$, in which peat layers are considerably compacted, the amount of peat compaction is positively related to LOI (van Asselen, 2011). For example, this is observed in the com- pacted peat layer in sequence $\mathrm{B}$, where lower compaction values are observed in the low-organic top of the peat layer.

Relatively high peat compaction values occur at the top of the peat layer in sequence A at $120-80 \mathrm{~cm}$ depth and at the top of the upper peat layer in sequence $C$ at $120-70 \mathrm{~cm}$ depth (Fig. 3). This can be explained by artificial lowering of the phreatic groundwater level in this agricultural area, which causes compaction and oxidation that both lead to an increase in the dry bulk density in the zone above and just below groundwater level (see Sect. 2). In sequence B the peat layer is situated too deep for groundwater level lowering to have any effect. Furthermore, high values occur beneath the natural levee and crevasse-splay deposits in sequence B and C respectively, due to the overburden weight. Also, at the base of sequence A the amount of compaction increases, which may be attributed to palaeo-groundwater level fluctuations, (auto)compaction and/or fluctuations in the hydrostatic pressure (Fig. 3).

\section{Discussion: assessing the potential of Holocene deltaic sequences for subsidence due to compaction}

The calculated compaction values for the sequences A-C indicate the potential for future subsidence due to compaction for comparable delta settings. For example, strongly compacted peat beneath thick natural levee deposits (Fig. 2, sequence B) is less vulnerable for future subsidence due to compaction than an uncompacted thick peat sequence with- 
Table 1. Relative potential of key sequences for peat compaction, based on lithological composition. For the lithological built-up of the sequences see Fig. 2.

\begin{tabular}{ll}
\hline Sequence & Compaction potential \\
\hline G & High \\
A & \\
F & \\
E & \\
C & \\
D & \\
H & \\
B & Low \\
\hline
\end{tabular}

out clastic overburden (Fig. 2, sequence G). Based on the lithological sequence composition and its properties, the relative potential for future subsidence due to peat compaction can be estimated (Table 1). In addition, the depth of the groundwater level can affect peat compaction: a drop in the pore water pressure following groundwater level lowering may induce additional compaction, and oxidation, of the peat sequence (van Asselen et al. 2009, 2010). This should be taken into account in assessing the compaction potential at locations where the groundwater table has been significantly lowered.

In summary, assessing the relative potentials for peat compaction of Holocene deltaic sequences requires determining the (1) lithological composition of the sequence, (2) the geotechnical properties of the different lithologies, which is predominantly a function of organic-matter and clastic content, and post-depositional processes of loading, and physi$\mathrm{cal}$, geochemical and biological processes, determining the present degree of compaction and geotechnical properties, and (3) the effective stress, which is a function of the weight of the overburden and pore water pressure that is influenced by respectively the built-up of the sequence and its properties and fluctuations in groundwater level or the absence thereof. Based on this information, the future potential for additional subsidence due to peat compaction can be estimated.

\section{Conclusion}

The potential for subsidence due to peat compaction of Holocene deltas is mainly determined by the 3-D distribution of different lithologies, and associated geotechnical properties, in the subsurface. In this study the amount of compaction within 3 sequences that are representative for distal deltaic settings is determined to assess the potential of comparable sequences in other deltas. In all sequences A-C the peat layers are compacted. Relatively high compaction values occur in peat layers within approximately $120 \mathrm{~cm}$ below surface, which are subjected to compaction and oxidation following groundwater level lowering. Furthermore, high amounts of compaction occur in peat layers beneath nat- ural levee and crevasse-splay deposits, and at the base of the Holocene sequences, due to the weight of the overburden. In compacted peat layers, high-organic peat generally compacts more than low-organic peat.

\section{References}

Berendsen, H. J. A. and Stouthamer, E.: Late Weichselian and Holocene palaeogeography of the Rhine-Meuse delta, the Netherlands, Palaeogeogr. Palaeocl., 161, 311-335, 2000.

Bos, I. J.: Architecture and facies distribution of organic-clastic lake fills in the fluviodeltaic rhine-meuse system, the Netherlands, J. Sediment. Res., 80, 339-356, 2010.

Bird, M. I., Fifield, L. K., Chua, S., and Goh, B.: Calculating sediment compaction for radiocarbon dating of intertidal sediments, Radiocarbon 46, 421-435, 2004.

Church, J. A., Clark, P. U., Cazenave, A., Gregory, J. M., Jevrejeva, S., Levermann, A., Merrifield, M. A., Milne, G. A., Nerem, R. S., Nunn, P. D., Payne, A. J., Pfeffer, W. T., Stammer, D., and Unnikrishnan, A. S.: Sea Level Change, in: Climate Change 2013: The Physical Science Basis. Contribution of Working Group I to the Fifth Assessment Report of the Intergovernmental Panel on Climate Change, edited by: Stocker, T. F., Qin, D., Plattner, G.K., Tignor, M., Allen, S. K., Boschung, J., Nauels, A., Xia, Y., Bex, V., and Midgley, P. M., Cambridge University Press, Cambridge, UK, New York, NY, USA, 2013.

Cohen, K. M.: Differential subsidence within a coastal prism: lateGlacial - Holocene tectonicsin The Rhine Meuse delta, the Netherlands, PhD thesis Utrecht University, Utrecht, the Netherlands, Geographical Studies, 316, 2003.

Cohen, K. M.: 3D Geostatistical interpolation and geological interpretation of paleo-groundwater rise in the Holocene coastal prism in the Netherlands, in: River Deltas - Concepts, models, and examples, edited by: Giosan, L. and Battacharya, J. P., SEPM Special Publication, 83, 341-364, 2005.

Erban, L. E., Gorelick, S. M., and Zebker, H.: Groundwater extraction, land subsidence, and sea-level rise in the Mekong Delta, Vietnam, Environ. Res. Lett., 9, 1-6, 2014.

Gouw, M. J. P.: Alluvial architecture of the Holocene Rhine-Meuse delta, the Netherlands, Sedimentology, 55, 1487-1516, 2008.

Gouw, M. J. P. and Erkens, G.: Architecture of the Holocene RhineMeuse delta (the Netherlands) - A result of changing external controls, Neth. J. Geosci., 86, 23-54, 2007.

Heiri, O., Lotter, A. F., and Lemcke, G.: Loss on ignition as a method for estimating organic and carbonate content in sediments: Reproducibility and comparability of results, J. Paleolimnol., 25, 101-110, 2001.

Stouthamer, E.: Sedimentary products of avulsions in the Holocene Rhine-Meuse Delta, the Netherlands, Sediment. Geol., 145, 7392, 2001.

Stouthamer, E. and Berendsen, H. J. A.: Factors controlling the Holocene avulsion history of the Holocene Rhine-Meuse delta (the Netherlands), J. Sediment. Res. A, 70, 1051-1064, 2000.

Stouthamer, E., Cohen, K. M., and Gouw, M. J. P.: Avulsion and its implications for fluvial-deltaic architecture: insights from the Holocene Rhine-Meuse delta. in: From River to Rock Record: The preservation of fluvial sediments and their subsequent interpretation, edited by: Davidson, S. K., Leleu, S., and North, C. P., Society for Sedimentary Geology, 11, 215-232, 2011. 
Terzaghi, K.: Theoretical Soil Mechanics, John Wiley and Sons, New York, USA, 510 pp., 1943.

van Asselen, S.: The contribution of peat compaction to total basin subsidence: Implications for the provision of accommodation space in organic-rich deltas, Basin Res., 23, 239-255, 2011.

van Asselen, S. and Roosendaal, C.: A new method for determining the bulk density of uncompacted peat from field settings, J. Sediment. Res., 79, 918-922, 2009.

van Asselen, S., Stouthamer, E., and Van Asch, Th. W. J.: Effects of peat compaction on delta evolution: A review on processes, responses, measuring and modelling, Earth-Sci. Rev., 92, 35-51, 2009. van Asselen, S., Stouthamer, E., and Smith, N. D.: Factors controlling peat compaction in alluvial floodplains - A case study in the cold-temperate Cumberland Marshes, Canada, J. Sediment. Res., 80, 155-166, 2010.

van Asselen, S., Karssenberg, D., and Stouthamer, E.: Holocene peat compaction in fluvial lowlands: Implications to subsidence within deltas, Geophys. Res. Lett., 38, L24401, doi:10.1029/2011GL049835, 2011.

van de Ven, G. P.: Leefbaar laagland. Geschiedenis van de waterbeheersing en landaanwinning in Nederland, Utrecht: Uitgeverij Matrijs, 456 pp., 2003. 